\title{
Religion and Marriage in the Book of Ruth: The Implications for Contemporary Nigerian Christians
}

\author{
Christian Ikenna Umeanolue* \\ DOI: http://dx.doi.org/10.4314/ujah.v12i2.7
}

\begin{abstract}
This paper made a survey of the Old Testament book of Ruth with special interest in the marriage between Ruth and Boaz. The work considered the positive impact of this marriage for the Judeo-Christian world especially as manifested in the personalities of King David and Jesus Christ who of course came from the lineage of Boaz and Ruth. The menace of discriminations among contemporary Christians in choosing marriage partners can be stopped through the proper understanding and internalization of the message of the book of Ruth on marriage. This understanding is necessary for the effective and sincere practicing of Christianity in Nigeria bearing in mind that it is the same God that created mankind in his own image.
\end{abstract}

\section{Introduction}

The issue of mixed marriages or intermarriages stand criticized among contemporary Nigerian Christians. Various people in the world have practiced different types of religion and marriage system. In a pluralistic society like Nigeria, religion has been an obstacle to marriage contracts. So many marriage engagements have been thwarted as a result of religious beliefs. In the book of Ruth, the marriage between Ruth and Boaz is an exceptional case. Hinson (1992) agreed with the idea of some scholars that the book of Ruth was written as a protest against the religion of Israel which forbade mixed marriage especially during the period of Ezra 
and Nehemiah who tried to make Yahweh a discriminatory God. Ruth was a Moabitess and was integrated from being a foreigner to a Jew through intermarriage and her character distinguished her. The genealogy as recorded in the book of Ruth shows that Ruth is the great-grand mother of David, Israel's greatest king (Ruth 4:18-22). Henry (1991) commented, "Ruth is hereby brought in among the ancestors of David and Christ, which was the greatest honour. The genealogy is here drawn from Pharez, through Boaz and Obed, to David, and so leads towards the Messiah" (p. 380). Intermarriage between Ruth and Boaz has fostered a binding relationship between the Jews and the Moabites which climaxed in the birth of the Saviour Jesus Christ who of course came from the lineage of David. For God's greatest favour was bestowed upon Israel through a mixed marriage the very thing that Ezra and Nehemiah frowned upon.

Laffey (1995) writing on the book of Ruth said that, "Ruth begins with a notice that the events recorded therein took place in the days when the judges were judging (Ruth 1:1) and ends with the notice that Ruth is an ancestor of King David (Ruth 4:17-22)" (p. 554). The period of the judges was between twelfth and eleventh centuries B.C. Famine struck Israel, and Naomi and her husband, Elimelech, left Bethlehem (in the tribe of Judah) for the nearby gentile nation, Moab. In Moab, Elimelech died, and the two sons, Mahlon and Chilion, eventually took Moabite wives, Orpah and Ruth. After ten years of marriage, both young men died; Naomi has now lost her entire immediate family. Soon, Naomi hears that the famine has subsided in Israel and she decides to return home. Her devoted daughters-in-law left with her, but Naomi tries to stop them from accompanying her to Israel. Because those women are young, Naomi blessed them with the wish that they return home and find new husbands. The two women insisted on remaining with her, 
but after Naomi reiterated her appeal, Orpah kissed her and went back. Naomi urged Ruth to return with Orpah but she, in one of the Bibles most moving passages, refused: 'Do not urge me to leave you, to turn back and not follow you. For wherever you go, I will go, wherever you lodge, I will lodge, your people shall be my people, your God shall be my God' (Ruth 1:16). To this Telushkin (1948) said:

In the thousands of years since Ruth spoke these words, no one has better defined the combination of peoplehood and religion that characterizes Judaism: "Your people shall be my people" ("I wish to accept the Jewish nation"), "Your God shall be my God" ("I wish to accept the Jewish religion"). (p. 359).

The problem with the attitude of Nigerian Christians in the contemporary time towards marriage is that they pretend to be religious even as they discriminate in their choice of marriage partners. Many Nigerian Christians are always blind at understanding the message of the book of Ruth as regards marriage to the extent that within Christianity today denominationalism has become an issue in marriage. Spiritual formation is not the debate. The matter is the church one attends. This ugly trend continues affecting the men and women of marriage age negatively especially the women counterparts, because many of them remain unmarried consequent upon they are waiting for marriage partners who are of the same faith, religion and tribe with them, hence the problem of this study.

The task before this paper is to make a study of the book of Ruth with regard to the marriage between Ruth and Boaz. The work also aims at investigating the implications of 
such marriage to the contemporary Nigerian Christians, because as Laffey (1995) said:

At a time when intermarriage was convenient and most likely common, many deemed it wrong (e.g., Ezra and Nehemiah). In such a period the book of Ruth would stand as strong testimony that non-Jewish people were not to be condemned out of hand. After all, a Moabite woman was King David's great grandmother. (p. $553)$.

\section{Conceptual Clarifications}

To have a better grasp of the topic of this paper, some key words will be clarified through their definitions. This will bring to bear on some conceptual definitions and some operational or contextual meanings of some key words on the topic. Concepts worthy of definition include religion and marriage.

\section{Religion}

According to Madu (2003), "Religion means man's recognition of the existence of power or powers beyond himself, who as it were, created the universe, sustains, preserves and provides for the universe" (p .46). From this perspective, one's religious belief has a way of influencing his or her choice of marriage. According to Durkheim (1964), "Religion is a unified system of beliefs and practices which unite into one single community called the church and all those who adhere to them" (p. 229). In this regard, religion in a nutshell means man's relationship with God. Man as a dependent being freely and internally acknowledges his dependence on God and expresses this in acts of individual communal worship. 
To Ugwu and Ugwueye (2004), "Religion could also be defined as the relationship between man and what he regards as sacred. It is man's recognition of a supersensible reality" (p. 3). Tillich (1963) defined religion as "the state of being grasped by an ultimate concern, a concern which qualifies all other concerns as preliminary and which itself contains the answer to the question of the meaning of life" ( $p$. 4). It is one's duty to God and to ones fellow human being. Also in the words of Carmody and Brink (2002), religion is "a system of symbols, myths, doctrines, ethics and rituals for the expression of ultimate relevance" (p. 1).

In a more comprehensive manner, Merriam (1980) defined religion as "the outward act or form by which men indicate their recognition of the existence of God or of gods having power over their destiny, to whom obedience, service and honour are due; the feeling or expression of human love, fear or awe of some superhuman and over-ruling power, whether by profession of belief, by observance of rites and ceremonies or by the conduct of life" (p. 250). Religion, therefore, could be defined as beliefs, feelings and practices involving the relationship between individual men and whatever they consider divine.

\section{Marriage}

The term marriage has been variously defined by scholars. Nmah (2004) said:

Marriage is the state in which men and women can live together in sexual relationship with the approval of their social group. Marriage could be regarded as covenant between man and woman. It is a divine agreement or sacred bond or contract involving a plurality of persons with certain goals. (pp. 68-69). 
Based on the above definition, marriage is a sacred bond between a man and a woman because it unites the husband and the wife to become one body and one soul. Chiegboka (2006) stated that "marriage is sacred because it is an institution that is both natural to man and divinely established and ordained by God from the very foundation of human race" (p. 10).

Fletcher (1973) defined marriage as "the union between a man and a woman" (p. 109). In the words of Obi (2001), "the union (marriage) between a man and a woman is for a duration of man's life" (p. 10). Obi's view is from the fact that marriage between a man and a woman is a life time union. Also, as a union between two opposite sex, marriage creates room for procreation.

Odunze (1982) opined that "marriage is seen as God's calculated permanent union between man and woman that might be helpful and useful to one another" (p. 25). And according to the view of Rahner (1975), "Marriage is a sexual fellowship, the structure of which varies considerably according to general social conditions" (p. 905). Thus, marriage is a religious and social institution by which a man and a woman are legally united and established as a new family. It is a voluntary union of a man and a woman for the purposes of helping each other and procreation.

\section{Marriage in the Old Testament}

Marriage has its basis in religion because of its theological background especially in the Old Testament. According to Kaiser (1975), "Marriage was God's gift to men and woman. Its purpose was to satisfy the social nature of mankind, for Adam found out by experience that he was lonely without human companionship" (p. 181). God agreed with Adam's estimate, adding 'It is not good for the man to be alone' (Genesis 2:18). The relationship that this marriage initiated 
was regarded in the Old Testament as indissoluble. That is the point of view expressed in Genesis 2:24; Deuteronomy 22:19-29; Jeremiah 3:1, Hosea 3:1-3; and Malachi 2:10-16. The people of the Old Testament practised different types of marriage including monogamy, polygamy and Levirate marriage. The marriage of Boaz and Ruth resembles that of Levirate marriage. Mckenzie (2002) defined levirate marriage as "the law which obliged a brother to marry the widow of his deceased brother if the brother died without male issue" (p. 506). This was a custom prevalent all over the Ancient Near East as also found in the book of Ruth.

Among the ancient Israelites, the only way to continue one's existence after death was through one's children. Absence of children, therefore, meant that one would cease to exist in Israel. In other to prevail such a tragedy, the levirate law provided that the deceased man's brother or closest male relative was to marry the deceased's widow so that the property or dowry as well as the fertility of the widow would be kept within the same patriarchal line. Such a practice made possible the continuation of the dead man's name and lineage in Israel as well as the retention of his property within the family. Among the Jews, marriage was however, highly honored. The Jews saw marriage as holy responsibility. Consequently, they interpreted Genesis 1 and 2 as God's formal institution of marriage.

The meaning of marriage and human sexuality is given in the narrative of God's creation of woman (Genesis 2:4-24). There the Old Testament text pointedly emphasizes the value and worth of man and woman in mutual relationship. As early as Genesis 2:27 man and woman were equally declared to be made in the image of God. The theological perspective of Genesis 2 is that God has created a garden for man's pleasure, animals to serve him, and women for companionship. Man's solitude and loneliness were 
declared to be a condition that was not good'. Man had been made to be a social being. Therefore, God made a 'helper suited to him' (Genesis 2: 20). Such a correspondence could not be found in the animals that were named by Adam and were subservient to him.

The prophets made an allegory of marriage. Turning from God to idols, they said, is like the sin of adultery (Jeremiah 3:9; Ezekiel 23:37). With this insight came the divine revelation that God was a husband to faithless Israel (Isaiah 54:5). Despite Israel's sin, God did not reject them but through the prophets (especially Hosea) called them back to renew their intimate marriage relationship with him. This image undermines the grace of God. The sin of rejecting God violates the most intimate of relationship. Yet God continues to love and to forgive.

\section{The marriage between Ruth and Boaz: An x-ray}

The marriage between Ruth and Boaz as recorded in the Old Testament book of Ruth was weaved around the custom of levirate marriage prevalent in ancient Israel. Naomi thinks of Ruth's future and arranges things so that Boaz will marry Ruth eventually. Naomi had to explain to Ruth what she must do to show Boaz that she was interested in marrying him. Naomi sets matters moving by asking whether she would seek rest for Ruth.

McKenzie (2002) defined Boaz as, "Kinsman of Naomi, a wealthy landowner of Bethlehem, who married Ruth (Ruth 2:1ff); an ancestor of David" (p. 100). It was Naomi's initiative that Ruth gets married to Boaz and Naomi tells Ruth that night, Boaz will be winnowing barely at the threshing floor. Naomi instructs Ruth to wash and anoint herself. Having prepared herself in this way, Ruth is to go down to the threshing floor, but not to make herself known to Boaz until he finished eating his food (Ruth 3:1-5). These 
instructions given to Ruth by Naomi now come to the climax. Boaz lies down to go to sleep; Ruth is instructed to make the place where he lies. She is to come and uncover his legs and lie down there. The point of this perhaps was to awake the man at his feet, because of cold. The position taken by Ruth also represented her as a petitioner. That represented the completion of Ruth's task as the role she must play to show that she is interested in the marriage. The above makes it clear that this describes a way whereby Ruth signified to Boaz her desire to marry him. Ruth carried out the plan and how Boaz received her overtures is a thing that is commendable. Ruth is not left long in doubt; Boaz's response is to pour down a blessing upon her (Ruth 2: 4, 12). He thinks that Ruth has shown more kindness at the beginning may be that which Ruth showed to Naomi.

Boaz made plain what was to be the order of things. First, he told Ruth to stay where she is; there is no point for her to go elsewhere. In the morning, Boaz promised action. There is a closer kinsman who has the right to marry Ruth if he chooses to exercise the right. Boaz took up Ruth's case, and called the other man who had the right to redeem, the one who was nearer than himself. He wanted to show that this man was not able to redeem Ruth. Boaz had a deep and abiding love and interest in Ruth and Naomi. The other man did not. The other man had not bothered himself about them at all and still did not care until Boaz challenged him and confronted him with the matter.

The other redeemer now confessed publicly that he was unable to redeem. Boaz bought and inherited what belonged to Elimelech, Malon and Chilion. He inherited Ruth as well. And he did not inherit her that she might be his slave; she was to be his wife. He was no longer the poor Moabite widow or even a humble gleaner in his field. Her place was to be at his side, in his home and in his heart. The entire harvest 
was hers. And more than that she now possessed not only the inheritance of Elimelech, Mahlon and Chilion but also all the wealth of Boaz. This mighty man of wealth was now at her disposal.

The marriage between Ruth and Boaz is a classical integration of two religions. Ruth was a Gentile and stranger to the Jewish religion. She was eventually related to Boaz by marriage. Intermarriage between Ruth and Boaz has fostered a binding relationship between the Jews and the Moabites, which climaxed in the birth of Jesus Christ, the saviour of the whole world who of course came from the lineage of David.

\section{Implications of Boaz's marriage with Ruth for Contemporary Nigerian Christians}

The marriage between Ruth and Boaz presents a lesson before contemporary Nigerian Christian that we should be against discriminations in choosing marriage partners. Christians should encourage mixed marriages once the man and woman marrying themselves agree to dwell together under one religion or faith. Ruth left her people, her nation and her god Chemosh to cling and follow her mother-in-law and eventually to marry Boaz. To this, Henry (1991) comments, "In the conversion of Ruth the Moabitess, and the bringing of her into the pedigree of the Messiah, we have a type of calling of the Gentiles in due time into the fellowship of Christ Jesus our Lord" (p. 372). Imagine a Moabitess getting married to someone of the Jewish race who sees themselves as the only people of God. Jews have always believed that God is peculiar to them and it is not in their character to marry a non-Jew. They discriminate against other nations, race etc. But, Boaz loved and married Ruth, a Moabitess.

Boaz's marriage with Ruth points to the contemporary Nigerian Christians that God is always willing to accept any 
stranger or foreigner who accepts to be part of his covenant relationship. Jews often despised the Moabites, but Ruth was loved for her faithfulness. Her modesty and virtue won the admiration of Boaz who eventually indicated interest in marrying her. Hence, Christian women especially the young ones who are seeking for marriage partners should emulate Ruth's faithfulness, modesty and virtue.

The success of the marriage between Boaz and Ruth implies that God is a universal God. Religious sentiments and tribal discrimination are not supposed to count in marriage. Once there is love and understanding between the intending couple, their marriage should be encouraged. God as the creator of the universe is the God of all people there in. According to Menezes (2003):

The author of the Book of Ruth along with the author of the Book of Jonah and the Second Isaiah are outstanding examples of prophetic personages who criticized the narrow-minded, nationalistic and racist types of theology as represented in the Book of Ezra-Nehemiah, who tried to make of Yahweh national God, not to say a partisan god, who considered non-Jews as 'pagans', destined for Yahweh's wrath and rejection. (p. 115).

Ezrah and Nehemiah go so far as to annul marriages of Jews with non-Jews and consider such marriages as treachery to their God (cf. Ezra 9 and Nehemiah 10).

Boaz's marriage with Ruth, a foreigner was a source of satisfaction to God. Their marriage was blessed with a son, Obed who became the grand father of King David and an ancestor of Jesus Christ. So, the issue of intermarriage is not thing of tribal sentiment, it is a thing of religious formation of 
the individuals coming into marriages. Boaz's marriage with Ruth points to the Jews and Christians that God is willing to accept any foreigner who accepts to be part of his covenant relationship he has with them.

The author of the book of Ruth advocates universalism. He anticipates Paul of Tarsus who asks his opponent: "Is God the God of the Jews only? Is he not the God of the Gentiles also? Yes, of Gentiles also, since God is one!" (Rom 3: 29-30). Religious sentiments and tribal discrimination are not supposed to count in marriage. God is the God of all flesh and he does not discriminate between individuals, peoples and nations. He is a universal God, not a God to Jews alone but a God to all who profess faith in him.

\section{Christians' Attitude towards Intermarriages in the Modern Time}

In the contemporary time, the issue of mixed marriage or intermarriage has become an issue of strong debate among Nigerian Christians. Generally, Christians' attitude towards intermarriage is not encouraging. Some Christians forbid intermarriage drawing from 2 Corinthians 6:14 which says: "Do not be mismatched with unbelievers. For what partnership have righteousness and iniquity? Or what fellowship has light with darkness?" Some other Christians believe that anyone has the freedom to choose his or her partner for life, and that love has no boundaries. This attitude is found most often among those Christians who may be identified as progressive or liberal Christians. This is supported by 1 Corinthians 7:12-14 with the central sentence: "For the unbelieving husband is sanctified through his wife, and the unbelieving wife is sanctified through her believing husband".

Some Christian denominations do not allow their members to marry from other denominations. In other words, 
within Christianity in Nigeria, Christians discriminate among themselves in choosing marriage partners. For A. Obiagbosogu (personal communication May 24, 2010), the reason why some churches do not allow their members to marry people from other churches is to protect the faith and doctrines of their respective churches. Consequently, this continues affecting mainly the Christian ladies many of whom remain unmarried only because they are waiting for marriage partners who are of the same faith or church with them. This discrimination goes contrary to the marriage between Ruth and Boaz which has become a source of blessing to the whole world.

Apart from marital discrimination on the basis of faith, in the contemporary Igbo society of Nigeria which is dominated by Christians, one thing that is really counting casualties is the issue of intermarriages between the $O s u$ and the freeborn. An $O s u$ is someone sacrificed or dedicated to a deity as personal property of the deity whom he must serve all his life, taking care of his welfare from the proceeds of sacrifices to the deity and donations to the chief priest and custodian of the shrine. According to traditional belief in Igbo land, any man who marries an $O s u$ becomes one, and his offsprings inherit this dehumanizing segregation. In some cases, many Igbo ladies and men of marriage age had their dreams to marry their choices of partners crashed on account of this segregatory system.

Efforts are being made to abolish this inhuman practice of caste system. The churches are the front liners. They try their best to let followers know that to tag another human being created by God sub-human is an abomination before God and a sin. However, as much as the churches canvass for the end of this system, their parishioners speak from both sides of their lips, for while they condemn this caste system in the day time, they hide to discriminate against 
the people at night. How then could this system be abolished when there are lots of hypocrisy and betrayal on the matter from some people who call themselves Christians? Interestingly enough, some true Christians, who are both young men and women, who really believe that all human beings are created equal before God have married each other, sometimes against the wishes of their parents just to please God. But the fact remains that these bold and courageous young people are grossly in the minority, as majority of the freeborn lack the confidence to begin the dismantling of this discriminatory practice through intermarriages.

Therefore, discrimination in choosing marriage partners among Christians in the modern time cannot be denied. In other words, the issue of mixed marriage is still a problem among our Christians, no matter how some people try to play it down. Any system which could derail the plan of two lovers to marry themselves, on account of religious belief or social stratification is definitely anti-human, and therefore should be eradicated without further delay.

\section{Conclusion and Recommendations}

Religion influences marriage. It influenced Ruth's marriage to Boaz because Ruth came under the wings of the God of Israel to take refuge. Ruth being a foreigner and Moabitess had to nationalize as a Jew. The marriage between Ruth and Boaz helped to foster a binding relationship between the Jews and the Moabites. Of course, God can use other people and nations to work out his divine purpose and plan. Ruth the Moabitess became part of the lineage that had Abraham and produced figures to reckon with particularly David and Jesus Christ. God is a universal God and does not discriminate. Thus if Nigerian Christians can be faithful to God and to their fellow human beings knowing that God is one and created all mankind, marriage in our time can also be blessed 
irrespective of religion, tribe, colour and social status. The book of Ruth presents a lesson before us that we should stand up against discriminations in choosing marriage partners. Mixed marriage should be encouraged once the man and woman marrying themselves agree to dwell together under the same religion. For a smooth intermarriage, there should be religious acceptance and cultural adaptation. Ruth accepted the Jewish religion and adapted to the culture of the Jewish people. While choosing marriage partners, people should choose those whom they can agree with in religion. Ruth agreed with Boaz's religion.

\section{References}

Anderson, G. W. (1966). The History and Religion of Israel. London: Oxford University.

Anderson, G. W. (1978). The living world of the Old Testament $\left(3^{\text {rd }}\right.$ ed.). London: Longman.

Chiegboka, A.B.C. (2006). What God Has Joined Together: The marriage Bond in Canonical Doctrine and Jurisprudence, Nimo: Rex Charles \& Patrick.

Carmody, D. L. \& Brink, T. L. (2002). Ways to the Centre: An Introduction to World

religions. New York: Eve Howard.

Durkheim, E. (1964). The Elementary Forms of Religious Life. London: London Press.

Fletcher, R. (1973). The Theory of Family and Marriage. London: Holy Trinity.

Henry, M. (1991). The Book of Ruth. In Matthew Henry's Commentary on the Whole Bible (pp. 372-380). New York: Hendrickson.

Hinson, D. F. (1992). The books of the Old Testament: Old Testament introduction 2. London: SPCK. 
Kaiser, W. C. (1983). Toward Old Testament Ethics. Michigan: Grand Rapids.

Kizhakkeyil, S. (2009). The Pentateuch: An Exegetical Commentary. Bandra: St Pauls.

Laffey. A. L. (1995), Ruth. In R. E. Brown, J. A. Fitzmyer and R. E. Murphy. The New Jerome Biblical Commentary (pp. 553-557). London: Burns and Oates.

Madu, J. E. (2003). The Paradox of the "One" and the "Many" in Religion. Nkpor: Globe Communications.

Merriam, W. (Ed.) (1980). Encyclopedia of Religion. New York: Prentice Hall.

McKenzie, J. L. (Ed.) (2002). Dictionary of the Bible. Bangalore: Asian Trading Corporation.

Menezes, R. (2003). The Old Testament for Our Times. Bandra: St. Pauls.

Nmah, P. E. (2004). Basic \& Applied Christian Ethics: An African Perspective. Onitsha: Gucks Systems Int'l.

Obi, C. C. (2001). The Cultural Custom and Tradition. New York: Free Press.

Odunze, D. (1982). How to Prepare for Marriage. In Family Circle Programme, Owerri: Family Circle.

Rahner, K. (1975). Encyclopedia of Theology. London: Burns and Oats.

Tillich, P. (1963). Christianity and Encounter with World Religions. New York: Columbia University.

Telushkin, J. (1948). Biblical Criticism. New York: HarperCollins.

Ugwu, C.O.T. \& Ugwueye, L.E. (2004). African Traditional Religion: A Prolegomenon, Lagos: Merit International.

*Christian Ikenna Umeanolue is of the Department of Religion and Human Relations, Nnamdi Azikiwe University, Awka. 